\title{
Aspirin For Benign Prostatic Hyperplasia: Studying The Effect On Flow-Rate By A Self-Designed Flowmeter
}

\author{
Mahmood Sh Abdulkarim* \\ * Department of Urology / College of Medicine / Basrah University
}

\begin{abstract}
Objective: The study was conducted to determine the effect of acetylsalicylic acidor commercially called (Aspirin) on the flow rate of patients with benign prostatic hyperplasia by the use of a self-designed flowmeter.
\end{abstract}

Materials and Methods: This was a prospective study between May 2007 and September 2015, evaluating the effect of Aspirin $100 \mathrm{mg}$ in patients with benign prostatic hyperplasia on prostate symptom score and the maximum flow rate, using a flowmeter designed and assembled by the author. The total number of patients completed the study was 1338 patient, they were all assessed and flow rate measured both before given Aspirin and after one-year time.

Results: The international prostate symptom score had a reduction in its mean from15.431 $\pm 2.665 \mathrm{SD}$ to14.352 $\pm 2.455 \mathrm{SD}$ after one year of taking Aspirin, the maximum flow rate was increased from $7.66 \mathrm{ml} / \mathrm{sec} \pm 1.63 \mathrm{SD}$ to $9.26 \mathrm{ml} / \mathrm{sec} \pm 1.96 \mathrm{SD}$ in the same period.

Conclusion: Aspirin is effective in reducing the symptom score of patients with benign prostatic hyperplasia and improve the flowrate in such patients, using the economical self-designed and assembled flowmeter.

Key words: Aspirin, Benign prostatic hyperplasia, flow-rate, load cell

\section{Introduction}

In order to study the effect of Aspirin on the urinary flowrate in patients with benign prostatic hyperplasia (BPH)we needed a flowmeter which is an expensive instrument, for this purpose came the idea of assembling a relatively cheap device depending on available parts and knowledge in addition to free software that is available in the internet.
The first principle we depended on was the fact that density equals mass

divided by volume so volume is equal to mass divided by density, as we can approximate urine density to one, then volume is equal to mass in this situation, using this physical fact we were able to calculate the urine volume flow rate per unit time by calculating mass flow per unit time by measuring mass by load cells and using special 


\section{Email:utjmed@utq.edu.iq}

software we were able to combine mass flow per unit time that is the urine flow rate.

\section{Density $=$ mass/volume}

Thus volume $=$ mass/density

And since density of urine $\approx 1$

Then volume =mass

The load cell is used to measure the urine mass and by connecting it to a computer using a special software freely downloadable from the internet we were able to measure exactly the flow rate of urine per unit time. Load cells are sensitive tools that can measure and detect even the slightest change in mass over its surface and equally transmit electrical impulses reciprocal to the mass change. These impulses can be graphically displayed by connecting the load cell directly to any computer or laptop(fig. 1) requiring simply the download of a free software from the internet. Through this software one can control the starting and ending points of recording of flow by which it can give more accurate values of flow rate than the flowmeters in the market as they tend to start and stop automatically thus giving false low flows specially in those patients with urethral stricture as it will divide the volume over a very prolonged time taken to empty the bladder. At this time there is no flow but just time recording, thus reporting a low flow-rate.

There is no doubt that benign prostatic hyperplasia is a common disease of elderly, with an increasing incidence with age reaching up to $80 \%$. Above the age of 70 , the decrease of urine flow rate is one of the important presenting symptoms that is produced by the increasing size of the gland and by the increase of the tension by the smooth muscles. ${ }^{1,2}$ Inflammation is suggested to be a cause or exacerbating factor for symptoms in general and flow-rate in particular. ${ }^{3}$ The logical conclusion for this fact is that antiinflammatory drugs can play role in improving symptoms and flow rate of patients with BPH. Aspirin is one of these anti-inflammatory drugs. It is acetylsalicylic acid, one of the nonsteroidal anti-inflammatory drugs. It inhibits prostaglandin synthesis through inhibition of prostaglandin endoperoxide synthase (PGHS) or cyclooxycxdgenase (COX) synthesis. By these mechanisms of action aspirin act as an analgesic, antipyretic, antiinflammatory or antithrombotic factor. ${ }^{4}$ for the last fifty years it was more commonly used as antithrombotic factor prescribed for patients either following or as prophylactic agent against stroke or cardiac ischemia. Therefore, it was not uncommon to face elderly patients with $\mathrm{BPH}$ and were using Aspirin .Our study objective was to observe those patients with $\mathrm{BPH}$ and who were started on Aspirin by a physician for medical causes and to monitor their urine flow rate and record their symptom score.

\section{Materials and Methods}

During the period between May 2007 to September 2015, 1865 patients were enrolled in this study with the following criteria, all patients were above the age of 50 years, they were taking Aspirin $100 \mathrm{mg}$ for the first time, it was prescribed by a physician 


\section{Email:utjmed@utq.edu.iq}

as prophylaxis following stroke or cardiac infarct. They had a normal prostatic specific antigen with enlargement of the prostate and they had outlet obstructive symptoms. We have excluded all other causes, like malignancy, stricture, stone or neurological causes. This was done by proper history, thorough examination and investigation. The number of patients who completed the study was 1338 patients, this was due to losing patients for several reasons, some did not tolerate aspirin because of its side effects, others were incompliant in taking the drug, some patients did not complete the study because of death and others did not attend for follow up. All patients had a score made depending on the international prostate symptom score (IPSS) and measurement of the maximum urine flow rate (Qmax) at the beginning of the study before taking Aspirin and repeated one year later by the same self-made uroflowmeter. This flowmeter was simply assembled by connecting a load cell (FIT7A), it is an intelligent load cell we have dismantled from an old factory packaging line for filling cooking oil bottles(Fig. 2), coasting two hundred dollars, which was connected to a personal laptop by a free software (AED_ Panel32) downloaded to the laptop. A pan was placed on the surface of the load cell to collect voided urine from the patient (Fig. 3). All patients had two visits, an initial assessment before the start of using Aspirin and another one after one year of taking the drug, flowrate (Qmax) was recorded in both events. The results was assessed by using a statistical software IBM SPSS version 15.

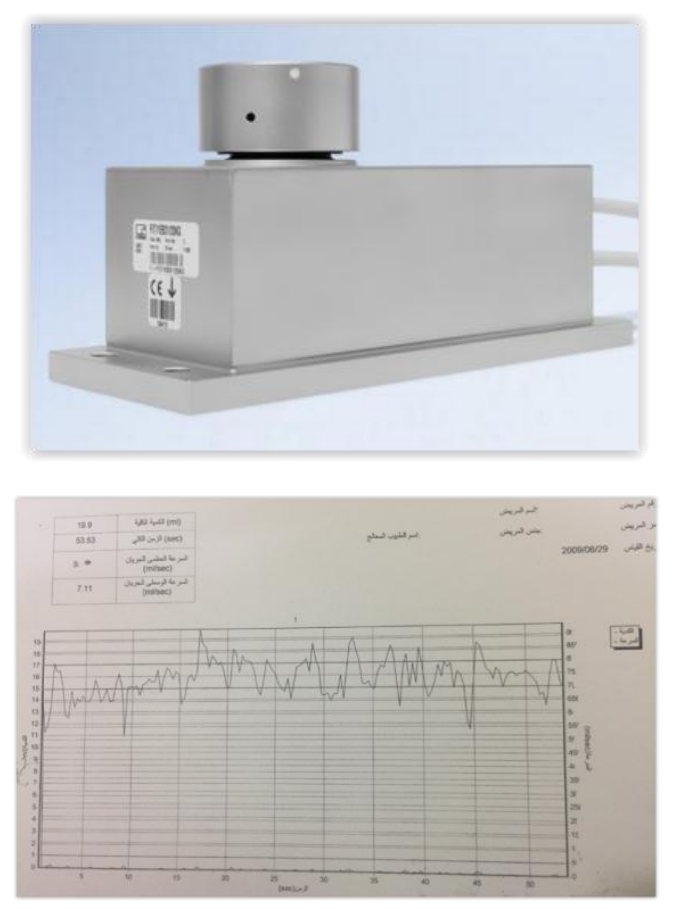

Figure 1 Load cell and graph showing measurements of flow rate

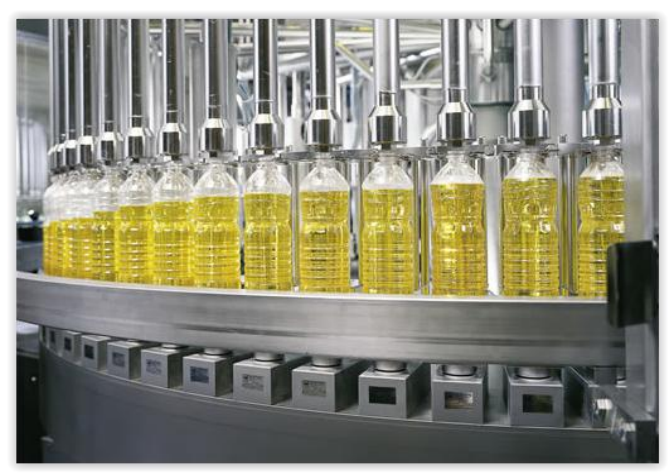

Figure 2 load cell at packaging line 

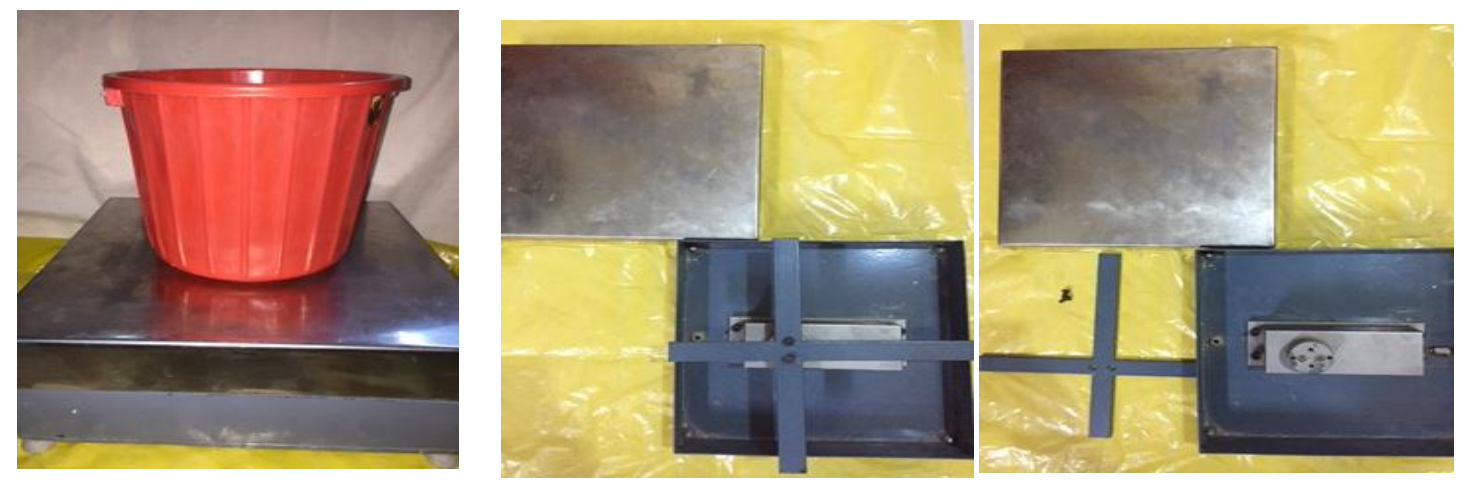

Figure 3 assembly of our flowmeter

\section{Results}

The study involved 1865 patients, the actual number of patients completing the study was 1338 patient. The age range of patients was from 52 years to 92 years with a mean age of 69.58 years. The level of prostatic specific antigen (PSA) in serum was in a range of $0.2 \mathrm{ug} / \mathrm{dl}$ to $4 \mathrm{ug} / \mathrm{dl}$, with a mean of $2.14 \pm 0.905 \mathrm{SD}$ (Table 1\&2).

The maximum flow rate $(\mathrm{Q} \max )$ of urine had a mean of $7.66 \mathrm{ml} / \mathrm{sec} \pm 1.63$ at the start of the study, it was only slightly increased after one year to a mean of 9.26 $\mathrm{ml} / \mathrm{sec} \pm 1.96 \mathrm{SD}$, after subjecting these data to statistical analysis using a paired sample $t$ test to compare the mean of the two readings it showed a significant difference $(\mathrm{t}(1337)=36.614, \mathrm{P} \leq 0.001)$ see Table 3 .

The international prostate symptom score (IPSS) was reduced from a mean of $15.431 \pm 2.665 \mathrm{SD}$ at the beginning of the study, to a mean score of $14.352 \pm 2.455 \mathrm{SD}$ after one year, comparing the two means by a paired sample $t$ test resulted in ( $\mathrm{t}(1337)$ $=27.654, \mathrm{P} \leq 0.001$ ) which is statistically significant difference (see Table 4 ).

Table 1 age summary measures

\begin{tabular}{|c|r|r|r|r|}
\hline $\mathbf{N}$ & \multicolumn{1}{|c|}{ Minimum } & Maximum & \multicolumn{1}{c|}{ Mean } & \multicolumn{1}{c|}{ Std. Deviation } \\
\hline $\mathbf{1 3 3 8}$ & 52.00 & 92.00 & 69.5845 & 10.54076 \\
\hline & & & & \\
\hline
\end{tabular}

Table 2 PSA level

\begin{tabular}{|c|r|r|r|r|}
\hline $\mathbf{N}$ & \multicolumn{1}{|c|}{ Minimum } & Maximum & \multicolumn{1}{c|}{ Mean } & \multicolumn{1}{c|}{ Std. Deviation } \\
\hline 1338 & .20 & 4.00 & 2.1449 & .90519 \\
\hline & & & & \\
\hline
\end{tabular}

Table 3 flow rate before and after Aspirin

\begin{tabular}{|r|l|r|r|r|r|}
\hline \multicolumn{2}{|c|}{} & Mean & \multicolumn{1}{c|}{ N } & Std. Deviation & Std. Error Mean \\
\hline Pair 1 & $\begin{array}{l}\text { Flowrate } \\
\text { before }\end{array}$ & 7.6622 & 1338 & 1.63802 & .04478 \\
\hline & $\begin{array}{l}\text { Flowrate } \\
\text { after }\end{array}$ & 9.2668 & 1338 & 1.96981 & .05385 \\
\hline
\end{tabular}


Table 4: IPSS before and after the use of aspirin

\begin{tabular}{|l|r|r|r|r|}
\hline Measurement timing & Mean & N & \multicolumn{1}{|c|}{$\begin{array}{c}\text { Std. } \\
\text { Deviation }\end{array}$} & $\begin{array}{c}\text { Std. Error } \\
\text { Mean }\end{array}$ \\
\hline $\begin{array}{l}\text { IPSS before } \\
\text { IPSS after }\end{array}$ & 15.4312 & 1338 & 2.66535 & .07287 \\
\hline
\end{tabular}

\section{Discussion}

The good old drug aspirin in addition to its various indications can also play a role in benign prostatic hyperplasia pathogenesis by reducing the incidence of gland enlargement, improving symptom score and increasing flow rate to about $35 \%^{5}$. One way of doing that is through the effect of inhibition of the synthesis of prostaglandins ${ }^{6}$. Inflammation was found to be one important component of pathological specimen in patients with BPH but without an obvious clinical infection or bacteria being detected. ${ }^{7}$ There was a strong association of chronic prostatitis to enlargement of the prostate gland and there was also an increase in IPSS as described in 2016 by Curtis Nickel et al. ${ }^{8}$ There was another observation by Erol et al ${ }^{9}$ in 2006 They described a reduction in PSA in patients with BPH after being given combination of antiinflammatory and antibiotic. The above facts lead to the logical conclusion that anti-inflammatory drugs will have an effect on the symptoms and flow of urine in patients with BPH. In our study we evaluated the effect of aspirin on two factors the first was the symptoms of outlet obstruction in those patients represented by IPSS, the second factor was the urine flow in the form of maximum flow rate( $Q \max )$. There was a significant mean difference in IPSS of about -1.079 and an a similar mean difference in $(\mathrm{Q} \max )$ of 1.6 $\mathrm{ml} / \mathrm{sec}$ these results go with those of a study by Arman et al in $2013^{10}$, where the mean difference in IPSS was -2.89 and of the (Q max) was $0.86 \mathrm{ml} / \mathrm{sec}$ indicating a significant effect of aspirin. Reviewing the literature make it still under controversy. A study on one hand can show an even more significant figures and in few others showed no relation or even a reverse relation in the sense of an increase in IPSS and decrease in (Q max). Sacit et al ${ }^{10}$ reported a mean difference of IPSS of 2.5 and the mean difference in (Q max) was $2.2 \mathrm{ml} / \mathrm{sec}$, while Meigs et al ${ }^{11}$ reported an association of aspirin with cumulative incidence of BPH reporting an odd ratio of 1.2 , the same odd ratio of 1.2 was also reported by Kang et $\mathrm{al}^{12}$ for patients using Aspirin and Ibuprofen for one year and association with increased incidence of $\mathrm{BPH}$. The relation of inflammation and $\mathrm{BPH}$ was confirmed in more number of studies than those not in favor. Larger study groups were found to be associated with even more significant results an odd ratio was reported by other studies. ${ }^{13,14}$ 


\section{Email:utjmed@utq.edu.iq}

This study was conducted using a flowmeter assembled using low cost parts that enabled us to substitute the average flowmeter cost of 1500-2000 \$ by a simple easy to operate more accurate coasting $200 \$$, self-assembled flowmeter depending on simple physics and wide imagination.

Conclusion: Inflammation have a role in producing obstructive symptoms in patients with BPH, thus antiinflammatory drugs can relatively relieve these symptoms by its various actions. Aspirin with low dose is recommended to be used for patients with BPH to improve the flow of urine and relieve outlet obstruction symptoms in combination with other therapeutic agents usually used for treating BPH.

Simple basic facts that we learn in basic knowledge such as physics can come handy in developing tools needed in our clinical practice as the flowmeter used in this study.

\section{References}

1. Pettaway C, Lamerato L, Eaddy M, et al. Benign prostatic hyperplasia: racial differences in treatment pattern and prostate cancer prevalence. BJU Int. 2011; 108: 1302-1308.

2.Kirby R. The natural history of benign prostatic hyperplasia: What have we learned in the last decade? Urology 2000; 56: 3-6.

3. De Nuzio C, Kramer G, Marberger $\mathrm{M}$, et al. The controversial relationship between benign prostatic hyperplasia and prostate cancer: the role of inflammation. Eur Urol. 2011; 60: 106117.
4. Tanasescu S, Leveseque H, Thuillez C. Pharmacology of Aspirin. Rev Med Interne 2002; 21: 18-26.

5. Jennifer L, Debra J, Michael E, et al. Protective association between nonsteroidal anti-inflammatory drug use and measures of benign prostatic hyperplasia. Am J Epidemiology 2006; 164:760-768.

6. Thru A, TeruhikoY, and Hiromi K. Effectiveness of a nonsteroidal antiinflammatory drug for nocturea on patients with benign prostatic hyperplasia: A prospective nonrandomized study of loxoprofen sodium $60 \mathrm{mg}$ once daily before sleeping. Acta Med Okayama 2004; 58: $45-49$.

7. Theyer G, Kramer G, Assmann I et al. Phenotypic characterization of infiltrating leukocytes in benign prostatic hyperplasia. $L a b$ Invest 1992; 66: 96-107.

8. Curtis J,ClausG,RamiroC,et al. Chronic prostate inflammation is associated with severity and progression of benign prostatic hyperplasia ,lower urinary tract symptoms and risk of acute urinary retention. J Urol 2016; 196: 1-6.

9. Erol H, Beder N, Caliskan T, et al. Can the effect of antibiotherapy and anti-inflammatory therapy on serum PSA levels discriminate between benign and malign prostatic pathologies? UrolInt 2006; 76: 20-26.

10. SacitN,ErtugrulS,Osman K, et al.The effect of combined therapy with tamsulosin hydrochloride and meloxicam in patients with benign prostatic hyperplasia symptoms and impact on nocturea and sleep 
Thi-Qar Medical Journal (TQMJ): Vol.(13), No.(1), 2017

Email:utjmed@utq.edu.iq

quality.Int. Braz J Urol 2013; 39: 657662.

11. Mieg J, Mohr B, Barry M, et al. Risk factors for clinical benign prostatic hyperplasia in a community based population of healthy aging men. J ClinEpidimiology 2001; 54:935-944. 12. Kang D,AndriolG, Van de vooren $R$ , et al .Risk behaviors and benign prostatic hyperplasia .BJU Int. 2004; 93:1241-1245.
Web Site: https://imed.utq.edu.iq

13. Alcaraz A, Hammerer P, Tubaro A, et al. Is there evedince of a relationship between benign prostatic hyperplasia and prostate cancer? Findings of a literature review. Eur Urol. 2009; 55: 864-875.

14. Sutcliffe S ,Platz E. Inflammation and prostate cancer : A focus on infections. Current Urol reports 2008; 9:

243-249 
الاسبرين لعلاج تضخم البروستات الحميد: دراسة تاثيره على معدل جريان الادرار باستخدام جهاز مقياس الجريان المصمم ذاتيا محمود شاكر عبد الكريم

خلاصة البحث

الهوف: أجريت الاراسة لتحديد تأثير حامض الأسيتيل ساليسيليك تجاريا يسمى (الأسبرين)

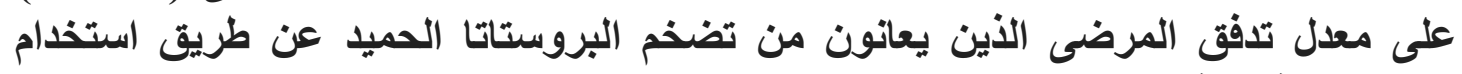
مقياس التدفق الأتي التصميم.

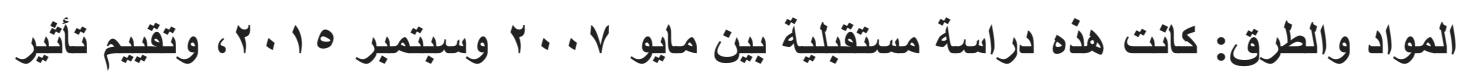

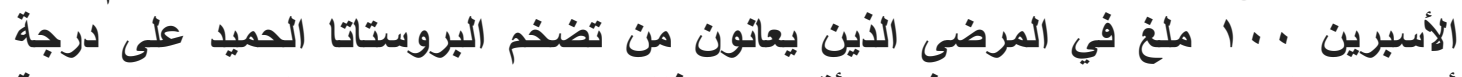

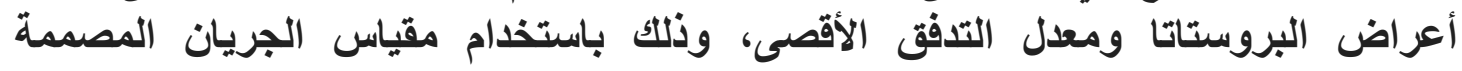

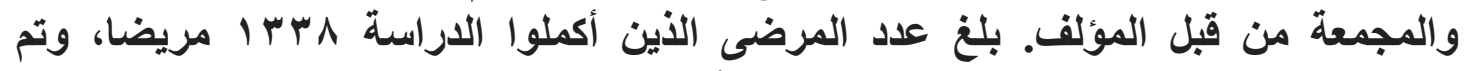

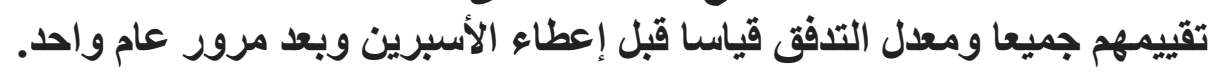

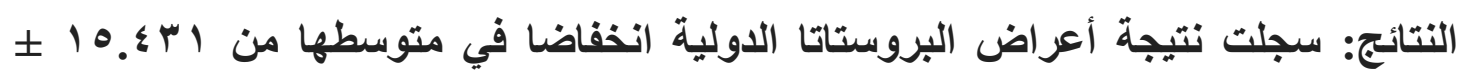

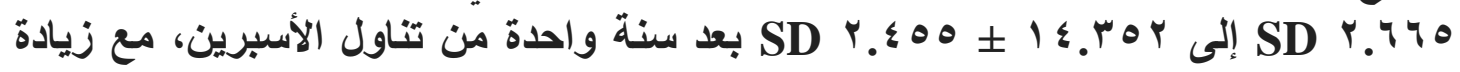

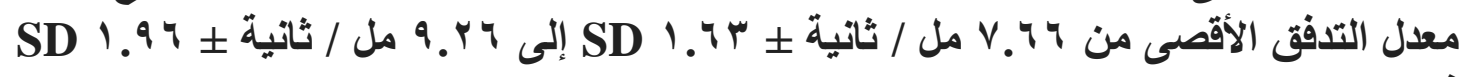
في نفس القترة

الاستنتاج: الأسبرين فعال في الحد من درجة أعراض المرضى الذين يعانون من تضخم

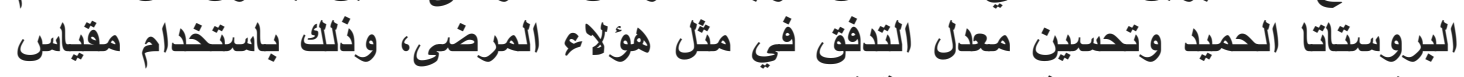
التذفق الاقتصادي المصممة والمجمعة ذاتينا. الكلمات الادالة: الأسبرين، تضخم البروستاتا الحميد، معدل التدفق، خلية الحمل 